\title{
Pandemic Response as Border Politics
}

\author{
Michael R. Kenwick $\odot$ and Beth A. Simmons $₫$
}

\begin{abstract}
Pandemics are imbued with the politics of bordering. For centuries, border closures and restrictions on foreign travelers have been the most persistent and pervasive means by which states have responded to global health crises. The ubiquity of these policies is not driven by any clear scientific consensus about their utility in the face of myriad pandemic threats. Instead, we show they are influenced by public opinion and preexisting commitments to invest in the symbols and structures of state efforts to control their borders, a concept we call border orientation. Prior to the COVID-19 pandemic, border orientation was already generally on the rise worldwide. This trend has made it convenient for governments to "contain" the virus by externalizing it, rather than taking costly but ultimately more effective domestic mitigation measures. We argue that the pervasive use of external border controls in the face of the coronavirus reflects growing anxieties about border security in the modern international system. To a great extent, fears relating to border security have become a resource in domestic politics - a finding that does not bode well for designing and implementing effective public health policy.
\end{abstract}

It stopped COVID, it stopped everything.

-Donald Trump, inspecting a section of concrete wall on the US-Mexico border,

23 June $2020^{1}$

Pandemics are imbued with the politics of bordering. For centuries, border closures and restrictions on foreign travelers have been the most persistent and pervasive means by which states have responded to global health crises. The ubiquity of these policies is not driven by any clear scientific consensus about their utility in the face of myriad pandemic threats. Instead it is a reflection of their palliative impact on societies predisposed to express concern about that which is foreign in times of crisis. In this way, the pervasive use of external border controls in the face of the coronavirus reflects growing anxieties about border security in the modern international system.

Pandemics reveal national character under radical uncertainty. Leaders may decide to rewrite their crisis playbook or may deploy well-worn tropes that have provided

Editor's note: This article is part of an online supplemental issue on COVID-19 and international relations. The authors were invited by $I O$ 's editorial team and guest editor Michael C. Horowitz. The manuscript was reviewed based on written non-anonymous reviewer comments and during an online workshop. The revised manuscript was evaluated by the $I O$ editorial team. We appreciate the support of Perry World House at the University of Pennsylvania for making this possible.

1. Quoted in Lemire 2020. 
reassurance in the past. The COVID-19 crisis has supplied plenty of evidence of the latter. Under uncertainty - and despite the recommendations of global health authorities - states that had already chosen to invest in border security have, on average, doubled down on that response to the pandemic. The politics that produce border security as a proper response to external threats have guided the COVID-19 response in many states as well. In this respect, pandemics-no less than migration waves or terrorist attacks-involve border politics.

As evidence of this claim, we analyze states' initial policy responses to the coronavirus spread. Borrowing from the interdependence literature, we consider policies of external versus internal adjustment. Policies can focus on externalizing the costs of pandemic control (by restricting travel and closing borders, for example) and/or they can internalize these costs (by regulating social distance, contact tracing, and regulating where and how many people gather). In responding to the coronavirus pandemic, states have enacted a panoply of protective policies, but none more pervasive or persistent than international border controls. ${ }^{2}$ Political leaders clearly attempt to frame the options and to manipulate public opinion. For some, borders become a political resource and securing them is the policy of choice. Such impulses are conditioned by the underlying script states follow when they embrace or filter The Other.

The COVID-19 pandemic is a rare opportunity to examine national politics in response to a (nearly) exogenous transnational shock. Pandemic politics provide subtle but suggestive evidence of international borders' important domestic role. As border scholars, we are especially concerned with how pre-existing routines of border governance influence the balance between policies of internalization and externalization. The initial policy mix is highly informative for understanding how international bordering is used to cope with major transnational shocks. States that have invested in the symbols and structures of border security are likely to respond to a pandemic with international travel restrictions, border closure, and potentially even international defection. And though there is no necessary tradeoff, the comfort states take in externalizing and scapegoating may undercut the national will to fight a pandemic from within.

For these reasons, we examine responses to the coronavirus pandemic through the lens of border politics. The first section demonstrates how common such externalization strategies are historically. Cooperative international efforts germinated in the nineteenth century but have been notoriously difficult to maintain. Hardening international borders in the face of perceived health threats is historically states' first (and sometimes only) move. The second section makes the case that domestic publics tend to be amenable to externalization strategies, and many politicians find it easy to oblige. We argue that this urge to close borders is often better characterized by political calculations made at a time of uncertainty and fueled by fear, rather than responsive to the scientific evidence alone. 
The third section is the empirical heart of the paper. Here we present a preliminary foray into the evidence connecting border governance, internal mitigation policies, and externalization through border restrictions. We suggest that pre-existing scripts for security tend to resurface in the face of pandemic uncertainty: physical border investments are strongly associated with border restrictions in the face of the COVID-19 pandemic, but are weakly, perhaps even negatively associated with stringent internal mitigation strategies. These trends-and the variation around them-inform a much richer understanding of the broad ramifications of domestic and international border politics. We conclude that the coronavirus crisis underscores a need to refocus the international relations literature on broad issues of border governance currently salient in many parts of the world. ${ }^{3}$ In terms of policy, closed borders and unilateral action are poor substitutes for international cooperation and meaningful domestic health policies.

\section{Border Control and Closure: The Historical Pandemic Policy Default}

Pandemic threats require sudden and consequential decision-making by state leaders. Which types of policies are most likely to reduce the spread of the disease? Should actions be taken internally, at international borders, or both? How are the public health benefits weighed against their economic impact? The answers to these questions should depend first and foremost on the nature of the biological threat, its etiology, mode of transmission, fatality rate, and the capability of modern medicine to reduce its impact on the affected. At the time of outbreak, however, policy makers are operating with incomplete information as the scientific community works rapidly to better understand the threat. As a result, state leaders reach for tools through which they can most readily assert authority. For the past several centuries, this has meant controls at territorial borders.

The historical record provides clear evidence that pandemic responses have been concentrated at the territorial borders of political authority. The term "quarantine," for example, originates from the Italian quaranta giorni or forty days, the amount of time foreign ships were required to anchor offshore during the fourteenth century outbreak of the bubonic plague. Italian city states continued to use systems of armed patrol ships, observation posts, and horse patrols to enforce disease controls that lasted until the $1850 \mathrm{~s} .{ }^{4}$ Prior to the nineteenth century, countries often responded to pandemics through unilaterally applied and often redundant quarantine measures, whose inefficiency threatened international trade routes. ${ }^{5}$ Responses to two devastating cholera outbreaks in the mid-nineteenth century and outbreaks of yellow fever in

3. Simmons 2019.

4. Cliff, Smallman-Raynor, and Stevens 2009.

5. Arhin-Tenkorang and Conceição 2003. 
North America were also notable for their emphasis on combatting transmission through focused measures taken at the edges of each state's territorial jurisdiction.

This pattern of responding to pandemics through increased border control has persisted for centuries. A series of international conferences and conventions aimed at coordinating containment efforts focused on the use of quarantine measures, despite a dearth of scientific information to inform whether such measures would prove effective. Four international public health organizations were formed between 1850 and $1951,{ }^{6}$ marking a new scientific and public health information sharing and monitoring function but retaining their at-the-border focus. ${ }^{7}$ These measures almost always prioritized state authority. This "Westphalian system of public health" coordinated quarantines to protect trade rather than public health and was carefully calibrated to protect territorial sovereignty. ${ }^{8}$ Border regions remained focal for pandemic control, even though the effectiveness of these measures remained speculative.

Some militarized approaches have moderated over the years. For the most part states have abandoned the extreme cordons sanitaires - the use of military troops to contain disease at the border-used by France in the Pyrenees in 1821 in the face of an aggressive fever, at the border between Poland and Russia in 1918 to stop typhus from spreading west, and most recently during the Ebola outbreak in West Africa in 2014. ${ }^{9}$ Diseases thought to be uncontrollable were not targeted by border measures. Richard Cooper relates how the international organizations of the twentieth century largely ignored diseases that could not be quarantined, in addition to those like smallpox, which were assumed to be universal. ${ }^{10}$

Some scholars have observed important turning points in the latter part of the twentieth century. The League of Nations' specialized agencies were reputed to have performed better than its security organs, but beyond some localized successes (notable for their time) had limited health impact. ${ }^{11}$ In 1948 the World Health Organization (WHO) was founded and in 1951 it passed International Sanitary Regulations which created a single but narrow set of rules for quarantine. ${ }^{12}$ The idea was again to control disease with a minimum of interference with world travel and trade. ${ }^{13}$ These rules were expanded into the International Health Regulations (IHR) in $1969^{14}$ and again in $2005^{15}$ to cover a growing range of diseases and risks. The

6. 1902: Pan American Sanitary Bureau; 1907: Office International d'Hygiène Publique; 1923: Health Organization of the League of Nations; and 1948: World Health Organization. See Arhin-Tenkorang and Conceição 2003; Fidler 1999.

7. Arhin-Tenkorang and Conceição 2003.

8. Fidler 2004.

9. McNeil Jr. 2014.

10. Cooper 2001.

11. Pedersen 2007.

12. Stowman 1952.

13. Fidler 2004, 33.

14. World Health Organization, International Health Regulations (1969): Third Annotated Edition. Available at <https://apps.who.int/iris/handle/10665/224469>. Accessed 21 July 2020.

15. World Health Organization, International Health Regulations (2005). Select provision available at $<$ https://www.ncbi.nlm.nih.gov/books/NBK143718/>. Accessed 21 July 2020. 
IHR also called on WHO members to buttress public health capabilities at ports and airports "in ways that are commensurate with ... public health risks and which avoid unnecessary interference with international traffic and trade." 16 Notably, the IHR has had difficulty anticipating the internal measures that would be appropriate for novel public health threats.

Multilateral accomplishments in pandemic control were modest for most of the twentieth century. The eradication of smallpox, which was responsible for some 300 million deaths worldwide during the twentieth century, was no small feat but was more of a Third World intervention led by the superpowers than a broader cooperative response. ${ }^{17}$ Not until the AIDS epidemic of the late 1980s and the SARS outbreak of 2003 did interstate organizations actively promulgate internal measures to combat novel pandemics, often at the behest of non-state actors. ${ }^{18}$ Development support for domestic pandemic control replaced some of the singular emphasis on international borders as a control strategy. To some observers, the WHO's more active role signaled a turning point. According to David Fidler, "The SARS case study not only illuminates governance shifts in public health but helps highlight changes that may be occurring to the general structure and dynamics of international relations in the era of globalization." ${ }^{19}$ Even so, no state has surrendered or even significantly pooled its sovereignty over public health. Some even go as far as Indonesia to assert "viral sovereignty"- the right to any medical developments that are made on the basis of a flu strain originating within their territorial jurisdiction. ${ }^{20}$ Clearly, and in light of recent allegations of Chinese noncooperation and US withdrawal from the WHO, it is premature to pronounce the death of a "Westphalian" model of pandemic policy response.

Almost every analysis of the global response to pandemics mentions state sovereignty and social sensitivities over public health issues. Hygiene, norms of contact, trust in science, and personal rights and privacy are often fraught social issues, yet disease control may require domestically costly changes in beliefs and behavior. Lack of (or resistance to) scientific knowledge has made it easier to rely on border controls than on internal mitigation strategies. We believe a case can be made for the attractions of border security in the case of COVID-19, especially for states invested in a narrative of the need for defense at the border.

\section{The Case of COVID-19}

Border policies have been a big part of the response to containing viruses that know no boundaries. But why? In this section we set the stage for an answer. Our central claim is that despite the intensification of globalization, and (often) despite scientific

16. International Health Regulations (2005), Article 2.

17. See the Cold War context described in Manela 2010.

18. See for example the discussion in Elbe 2010.

19. Fidler 2004, 8.

20. Elbe 2010, 171. 
evidence, unilateral border control is a very tempting tool for sovereign states to wield in the face of a pandemic. A remarkable 186 countries responded to COVID-19 with external border restrictions, targeting travel from an average of 163 countries. ${ }^{21}$ By contrast, only 127 countries have enacted social distancing provisions, and often with much weaker enforcement. ${ }^{22}$ Land borders have also been particularly focal. By our count, ninety-two countries had fully or partially closed their land borders by 24 March 2020. Even the internal borders of the European Union saw a return to border controls rare since the establishment of the Schengen Zone. ${ }^{23}$ Rhetorical bordering is also on the rise with several state leaders speculating about the foreign origin of the virus, often in derogatory terms.

Such an overwhelming response might be understandable if science spoke with a clear voice about border restrictions. However, the choice to institute border controls and closures are not generally driven by the data. A review of the scientific evidence available before the COVID-19 outbreak suggests that border controls, as they are generally implemented, are a rather ineffective way to control pandemics. ${ }^{24}$ Most of these studies demonstrate that controls at the border must be implemented very early in the spread of the pandemic — often well before the available evidence clearly indicates a threat. Studies have shown that social distancing is more effective than border controls for delaying the peak of pandemic infections. ${ }^{25}$ There may be a limited case for small isolated island states such as New Zealand ${ }^{26}$ or Taiwan, but border closure alone has not been shown to be effective and has been recommended against by the World Health Organization. ${ }^{27}$ In short, even though travel bans and border restrictions are of limited utility — very stringent ones at best buying a week or so to put domestic measures in place ${ }^{28}$ - they are the policy of choice in most countries around the world.

\section{Pandemics and the Problem of Uncertainty}

Why reach for border restrictions? One reason is that pandemics almost always introduce radical uncertainty into decision making. Experience bears this out. The emergence of the novel H1N1 virus compounded a list of unknowns: the scale of the problem, the range of (initially) small-scale trade-offs, uncertainty around detection and treatment, and of course the probability that modest numbers of cases will result

21. Cheng et al. 2020.

22. Ibid.

23. For a list of notifications, see European Commission, "Temporary Reintroduction of Border Control." Available at <https://ec.europa.eu/home-affairs/what-we-do/policies/borders-and-visas/schengen/reintroduction-border-control_en>. Accessed 21 July 2020.

24. Bier 2020.

25. Cacciapaglia and Sannino 2020.

26. Boyd et al. 2017.

27. See Euronews 2020 and Bier 2020.

28. Wells et al. 2020 conclude that despite being some of the strictest in the world, China's "border control measures, such as airport screening and travel restrictions, have ... likely slowed the rate of exportation from mainland China to other countries, but are insufficient to contain the global spread of COVID19." [Italics added.] 
in widespread outbreak. ${ }^{29}$ And what is learned from previous experience is not always relevant across the range of pandemic cases; influenzas alone involve so much genetic variation that it is difficult to predict their behavior, leading virologists to characterize pandemic influenzas as "certain uncertainties." ${ }^{30}$ Importantly, uncertainty has consequences for whether, when, and which policy actions are taken. Uncertainty was probably a central reason for official decisional paralysis in the Ebola crisis, for example. ${ }^{31}$

Then there are the uncertainties introduced by governance structures and policy communication. Whether uncertainty is acknowledged can differ across governance levels, illustrated by the confusion between federal state and local authorities in the United States, Mexico, and Brazil, not to mention among the member states of the EU and the European Commission. ${ }^{32}$ Communicating uncertainty is a sensitive policy problem: to frankly admit uncertainty can undermine public confidence. ${ }^{33}$ One study found that the communication of uncertainty undermined collective action by "personalizing" responses to pandemic risks. ${ }^{34}$ Others have emphasized that the first-order problems associated with scientific and policy uncertainty are compounded when they reverberate throughout the economy, ${ }^{35}$ rendering the assessment of trade-offs even more problematic.

International borders are a handy heuristic for decision-making under uncertainty. They are focal and represent authoritative national power. Restricting them tends to impose lower costs on residents than internal restrictions on movement or business closures. Border restrictions are in this sense a good political bet for most leaders: they are fast and frugal. ${ }^{36}$

\section{Border Anxiety—a New Pandemic?}

Why and under what conditions are border restrictions considered a prudent policy choice? One possibility is that publics and politicians have been priming a narrative of "dangerous others." Contagious foreign disease is just one more example of the broad and deep border anxieties that we have seen evidenced across a spectrum of issues over the past few decades. ${ }^{37}$ This anxiety has been on display, for example, in debates in the United Nations General Assembly, where border issues are drastically on the rise as a proportion of all official public discourse, and have trended decisively negative over the past decade. ${ }^{38}$ It is possible that the general anxiety around non-state forces at the border has simply been reproduced as a motivated response to the COVID-19 pandemic.

29. Reflecting on H1N1, see Lipsitch et al. 2009.

30. Morens and Taubenberger 2011.

31. See Karlsen and Kruke 2018; Leduc and Liu 2020.

32. Versluis, van Asselt, and Kim 2019.

33. See Backus and Little forthcoming; Driedger, Maier, and Jardine 2018.

34. Davis 2019.

35. Baker et al. 2020.

36. This phrase comes from management decision making under uncertainty by pairwise comparison (Luan, Reb, and Gigerenzer 2019), but seems an appropriate description in this context as well.

37. For a discussion relating to migration, see Almond 2016.

38. Simmons and Shaffer 2019. 
Border anxieties are also reflected in changes to the built environment along international borders. It is well known that states have constructed walls and fences along these zones. ${ }^{39}$ Border crossings increasingly bristle with the infrastructural capacity to filter a broad range of threats-from smuggled goods to unwanted migrants to local militias and neighboring militaries. Land borders provide a stark visual impression of this development. Figure 1 displays the thickening of filtering capacity at the USMexico border over two decades, but the trend is worldwide. Satellite and high-altitude imagery reveal the uneven but unmistakable build up of official buildings, gates and barriers, and pull-out lanes where pedestrians and vehicles can be held for inspection. ${ }^{40}$
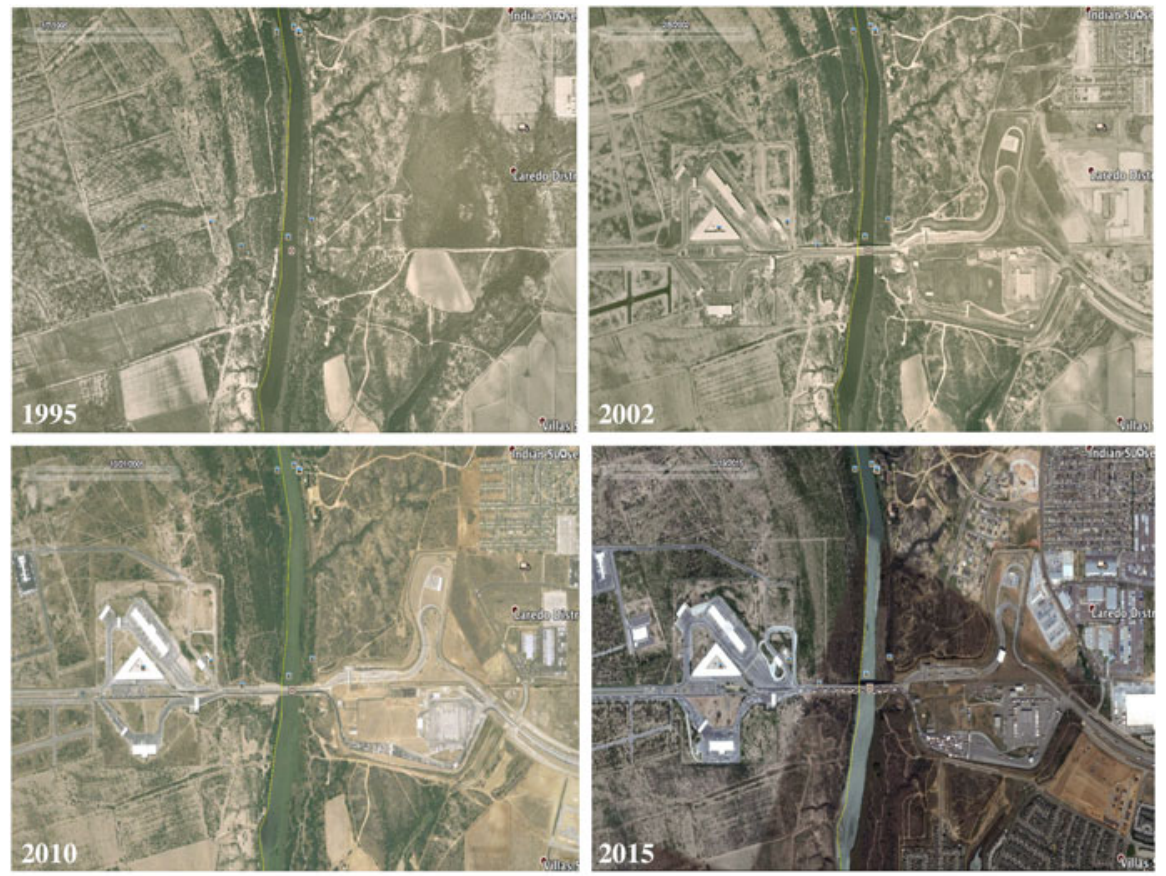

Note: Average border orientation scores range from approximately 0.8 in 2002 to 2.2 in 2015.

Source: Google Earth, at 27.5972898,-99.536867.

FIGURE 1. Example of the build-up of "filtering capacity" at the US-Mexico border near Laredo/Nuevo Laredo in 1995 (top left), 2002 (top right), 2010 (bottom left), 2015 (bottom right)

39. Avdan and Gelpi 2017; Carter and Poast 2015; Hassner and Wittenberg 2015.

40. Simmons and Kenwick 2020. 
The erection of walls, police stations, and filtering infrastructure at interstate borders demonstrates how focal borders have become for enacting national security policies. The concept of border orientation helps to summarize this trend over time and space. ${ }^{41}$ It taps the extent to which the State is committed to filtering the movement of goods and people into and out of its territory. Border orientation ranges from very permissive, where few means are taken to project control of state borders, to very controlling, where countries make large investments to assert control over ports of entry and the border region. Like many political traits, border orientation is latent and cannot be observed directly; it can, however, be inferred based on the physical investments manifest in the built environment. In our previous work, we have generated an estimate of border orientation using a latent variable modeling framework based on: (1) whether a country has built inspection facilities along roads crossing international borders, ${ }^{42}(2)$ whether a country disproportionately polices its borders relative to the interior region, and (3) whether a country has built border walls facing its neighbors. ${ }^{43}$ The scores generated by a latent model of observed infrastructural investments represent a commitment to display authority at the border, with higher scores representing more controlling border orientations.

Over the past twenty years, countries have increasingly displayed controlling orientations, reflecting a concern about real and perceived threats across international borders. As displayed in Figure 2, we estimate that average border orientation has increased over the past two decades, with an inflection point that coincides with the 2008 financial crisis. ${ }^{44}$ This growth indicates that countries were already primed to see their borders as a means of defense even before the risk of transnational contagion emerged. Not only have border closures spread more quickly than the virus did across borders, we are also seeing more unilateralism and fewer attempts to coordinate internationally than we did in previous historical eras. It is perhaps no wonder then that the "post-Westphalian" at-the-source responses Fidler associated with AIDS and SARS have given way to retrenchment. ${ }^{45}$

Borders are focal for pandemic policy, since they are an "obvious" starting point for a state to exert its authority. ${ }^{46}$ Border controls satisfy the need to do something quickly, decisively, and without raising questions of a state's legitimate right to act. This is clearly not true for actions taken by the WHO, ${ }^{47}$ nor for internal regulations to stay home: witness the protests that have sprung up around the United States

41. Ibid.

42. Data obtained from Carter and Poast 2015.

43. The resulting measure is approximately normal, with a mean centered near zero, and an approximate range of -3 to 3 .

44. As Simmons and Kenwick (2020) demonstrate, this pattern persists for virtually every region in the world with the exception of Western Europe.

45. Fidler 2004.

46. The international relations literature develops the idea of borders as focal point for purposes of making territorial claims internationally. Goemans and Schultz 2016. Our argument suggests an analogous purpose for domestic policy.

47. Buranyi 2020. 
but also in Europe, South Asia, Africa, and the Middle East. ${ }^{48}$ Border controls inconvenience relatively few nationals, yet satisfy the need for the State to appear to provide security. Meanwhile, border restrictions preserve possibly fictitious ideas that the threat is foreign, the State is competent, and the domestic population is and can be kept wholesome and healthy. For these reasons, border restrictions are attractive in a pandemic, especially for states that have invested in the symbols and structures of control.

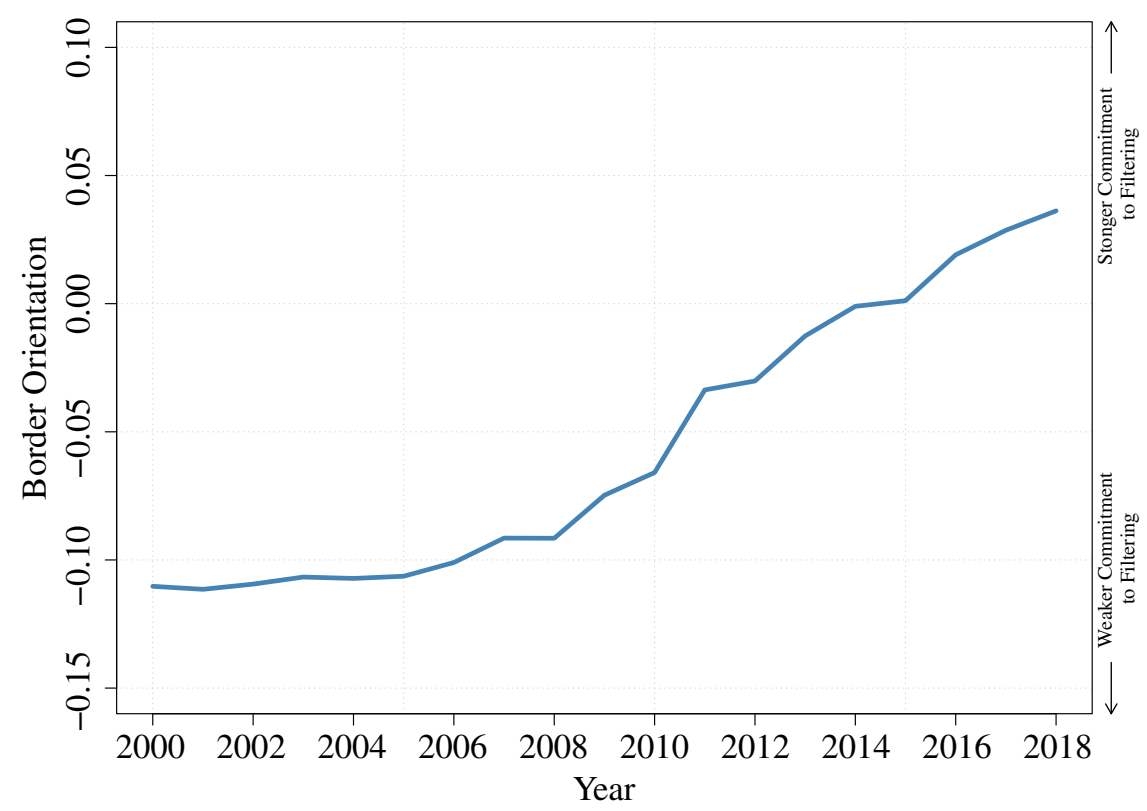

Notes: The figure shows estimates of border orientation, a latent concept tapping state ability to project its authority to filter entry and exit at borders and border crossings. Higher values correspond to an increased commitment to filtering at the border. Based on satellite imagery of border crossings, documentation of border walls and fences, and the ratio of police stations in $30 \mathrm{~km}$ border zones to the rest of a country.

Source: Simmons and Kenwick, 2020.

FIGURE 2. Average global border orientation is intensifying, 2000-2018

Public Opinion: Demand from Within. While border orientation is a characteristic of states, it often has a foundation in the fears and anxieties of the public. How does mass opinion about border politics set the stage for pandemic response? It is often much easier to sell externalized adjustments through border restrictions to 
domestic audiences than it is to sell them orders to cancel activities, socially distance, and stay at home. Not to mention those emasculating masks! ${ }^{49}$ Publics experience many of the same uncertainties and anxieties that their leaders do. In addition, they can readily be primed to accept border closures by leaders who are incentivized to engage in blame avoidance by framing pandemics as foreign invasions. ${ }^{50}$ Under these conditions, externalization is likely to be an easier sell than tough internal mitigation measures.

Available polls bear this out. Polls conducted in mid-March 2020 across twelve countries and sampling 12,000 people show that significant majorities-some reaching 80\%-support border closures as a response to the COVID-19 pandemic (Figure 3). Such high figures are surprising given the wording of the question: "We should close the borders of [my country] and not allow anyone in or out until the virus is proven to be contained." (Emphasis added.) Sixty-two percent of Americans agreed with this statement, even though it was worded to include a self-restriction (anyone). That proportion is about as high as support for border restrictions on migrants (not citizens) right after the 9/11 attacks. ${ }^{51}$ People appear to favor even stronger border restrictions in the current pandemic than they did following the dramatic terrorist attacks in 2001.

At the time these polls were taken, mid-March 2020, the United States already had about 1,300 confirmed cases and forty COVID-19 deaths within its borders. The virus was already within US borders. Almost all scientifically informed advice was that it was imperative to implement serious internal mitigation measures. Nonetheless, within three days of the poll, the United States government closed the Mexican and Canadian land borders (despite lower infection rates and deaths in those countries) to all non-essential traffic.

Extremely high majorities of the American public —about eight out of tenfavored travel bans against China and Europe in late March of 2020. Fewer-but still a majority-supported school closures and cancelling events, but of the $26 \%$

49. Carter 2020.

50. Such framing is historically common and includes targeting foreign countries as well as disfavored domestic minorities. See Kenny 2020.

51. For example, in three separate polls ranging between a month and six months after the 9/11 attacks, US residents answered as follows to these analogous questions:

Question: Do you favor or oppose temporarily sealing US (United States) borders and stopping all immigration into the US during the war on terrorism? $65 \%$ said yes.

Question: During the war on terrorism, do you favor or oppose each of the following measures? ... Sealing US (United States) borders and stopping all immigration for up to two years while the search for terrorists is conducted. $52 \%$ said yes.

Question: During the war on terrorism, do you favor or oppose each of the following measures? ... Sealing US (United States) borders and stopping all immigration for up to two years while the search for terrorists is conducted. $48 \%$ said yes. Source: author's database of polls administered in the United States on border security, various years and pollsters. 


\section{Statement: We should close the borders of my country and not allow} anyone in or out until the virus is proven to be contained

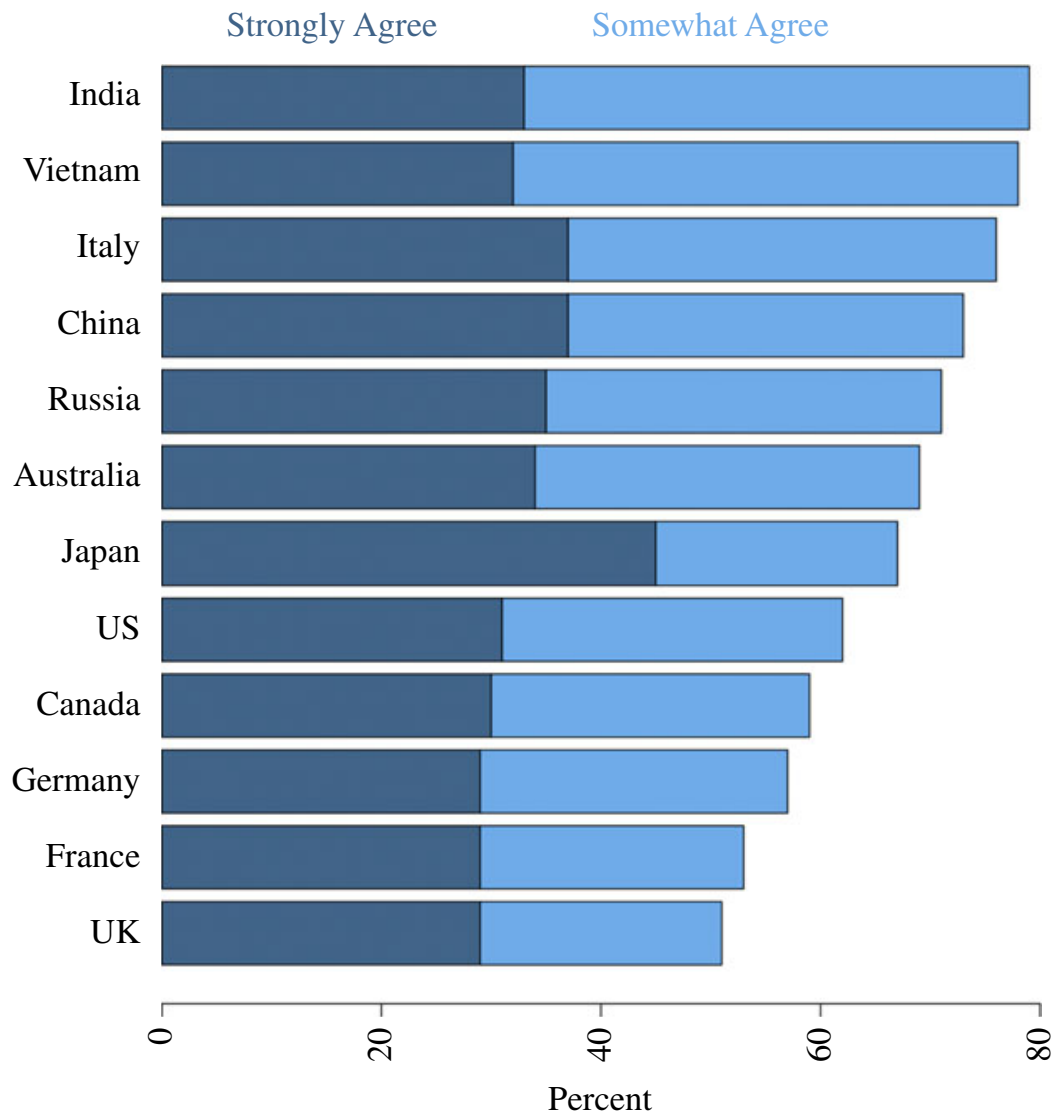

Source: IPSOS. https://www.ipsos.com/en/majority-people-want-borders-closed-fear-about-covid-19escalates.

FIGURE 3. Public opinion in twelve countries on border closure as a response to the COVID-19 pandemic, March 12-14, 2020

who said these internal measures were an overreaction, nearly three-quarters still supported travel bans. ${ }^{52}$ Despite clear evidence that the virus was already in the US, and 
as news of its spread mounted, more Americans favored travel bans than domestic mitigation policies.

Of course, we do not view domestic attitudes about border restrictions as independent of elite cues and national politics. The need to externalize can be stoked by divisive rhetoric and nationalism. In some cases, public health policies become securitized $^{53}$ in familiar ways. War allusions have peppered the speeches of leaders from the Queen of England ${ }^{54}$ to the US president ${ }^{55}$ to the Secretary General of the United Nations. ${ }^{56}$ Policy responses have in many cases displayed traces of such militarized rhetoric. Arguably, the securitization of pandemic influenza since the mid-1990s has resulted in policies "driven by national priorities and not the need for a coherent global public health response," ${ }^{57}$ among them border closures, especially by states whose authority was already cast to enhance border control.

In many countries, public opinion demands border protection in the face of the inherent uncertainty pandemics bring. A growing number of states are prepared to accommodate these fears with the authoritative symbols and structures of border security. The combination has consequences for how states have responded to the COVID-19 pandemic, as we will illustrate.

\section{Border Closures and COVID: An Empirical Investigation}

The COVID-19 pandemic has brought together the demand for protection from "foreign" virus threats with the supply of authoritative investments at the border to torque policy responses away from internal adjustments and toward externalization in the form of border closures. To illustrate the plausibility of at least the supply half of this claim, we use border orientation as a key explanatory variable, and rely on data provided by the Oxford COVID-19 Government Response Tracker as the dependent variable. ${ }^{58}$ This response tracker records information on whether and when governments have enacted various policies to combat COVID-19. At present, the data range is from 1 January to 17 June 2020. While these data are clearly not suitable to make broad claims about how the COVID19 crisis will be resolved, they are uniquely suited to exploring states' initial responses.

53. On securitization theory see Balzacq 2005; Stritzel 2007; Wæver 1995.

54. Landler 2020.

55. Washington Post 2020.

56. Ninth Secretary-General of the United Nations, Guterres 2020.

57. Kamradt-Scott and McInnes 2012, S107.

58. Hale et al. 2020. 
We make use of two measures derived from these data. First, to identify measures directed primarily toward foreign populations, we rely on the data set's international travel control indicator, which includes five ordered categories: no measures taken, screening, quarantine arrivals from high-risk regions, ban on arrivals from some regions, and ban on all regions or total border closures. While these measures impact both foreign populations and citizens returning from abroad, they nevertheless approximate external control measures implemented at international ports of entry. ${ }^{59}$ Second, we construct a weighted average of the internal measures countries take to mitigate the domestic spread of the virus. These include school closures, workplace closures, cancellation of public events, restrictions on gatherings, closure of public transport, stay at home requirements, restrictions on internal movement, and public information campaigns. ${ }^{60}$ Although the external control index is an ordinal five-point scale and the internal control index is virtually continuous, we transform each to range from zero, corresponding to minimum control, to 100, reflecting maximal controls. Comparing the stringency of response across these two dimensions approximates the balance of policies a country adopts that fall disproportionately on domestic and foreign populations.

Figure 4 displays the global mean values for internal and external control measures across time. While these two variables are measured on separate scales, their relationship to each other over time is telling. Countries responded to the global outbreak first with external controls, and only secondarily with internal control measures. That these external controls were often implemented at a time when the WHO recommended against their use further underscores the return to at-the-border controls as pandemic response, perhaps reflecting the intensifying concern about border security over the past two decades. However, this might also reflect a reasonable impulse to contain the virus before more painful mitigation strategies become necessary-after all, studies have shown that to be effective, restrictions such as travel bans must be imposed early. ${ }^{61}$ Yet some countries continued to ratchet up external controls even after containment had failed, as did the United States at its land borders with Canada and Mexico. Figure 4 reveals that countries have eased external controls more slowly than internal controls. This evidence is consistent with the externalization processes described in the previous section-in times of pandemic, there is an inclination to disproportionately implement costly policies that affect international actors relative to domestic constituents.

59. Future research should relax this assumption and specifically test for the distribution of expected costs by controlling for external trade/travel dependence.

60. The resulting measure is computed identically to the stringency index described in Hale et al. 2020 except that we remove the travel control indicator, given our interest in differentiating between policies targeting domestic and international populations.

61. See the studies reviewed in Bier 2020. 
Our central claim is that pandemic policy is shaped by border politics. By this we mean by the prior degree of investment a country had previously made in bolstering its authoritative presence at international land borders (border orientation). While virtually all countries have now adopted some form of restrictions on international movement, they have varied considerably both in the time it took them to implement these measures, and, crucially, the extent to which they were paired with other policies to mitigate the spread of the virus internally (the policy mix). This is important because studies show that border control does little more than buy precious days to implement much more effective mitigation policies nationally. Descriptively, border politics shape this critical mix: countries otherwise highly concerned with border security investments are faster in adopting controls that target foreign travel, but this alacrity is not always mirrored domestically.

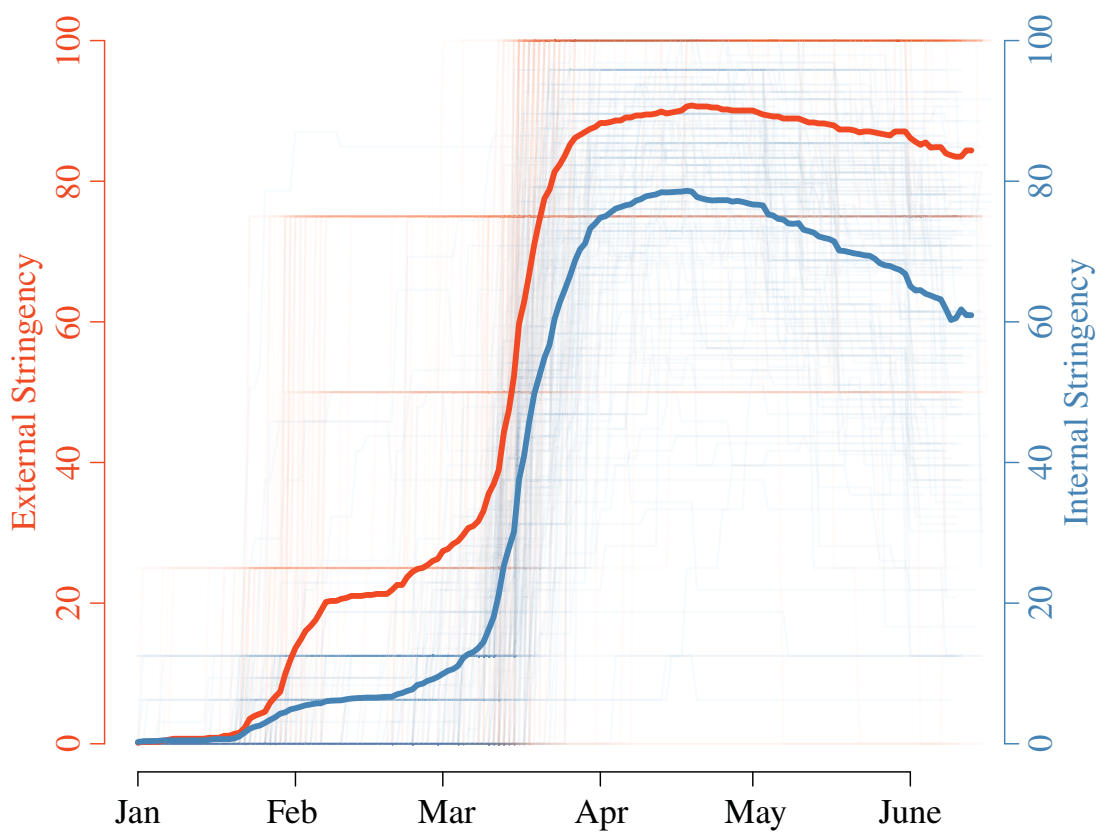

Notes: Global means reported in bold lines, with individual country time-series displayed in thin lines beneath. Stringency data generated from Hale et al. 2020.

FIGURE 4. External control measures are implemented faster and last longer than internal control

Figure 5 compares the average stringency of internal and external response measures to 2018 estimates of border orientation, with positive values corresponding to increased commitment to filtering movement along international borders. Border orientation is more highly correlated with the adoption of external measures $(\rho=0.395)$ than with internal control measures $(\rho=0.184)$. 

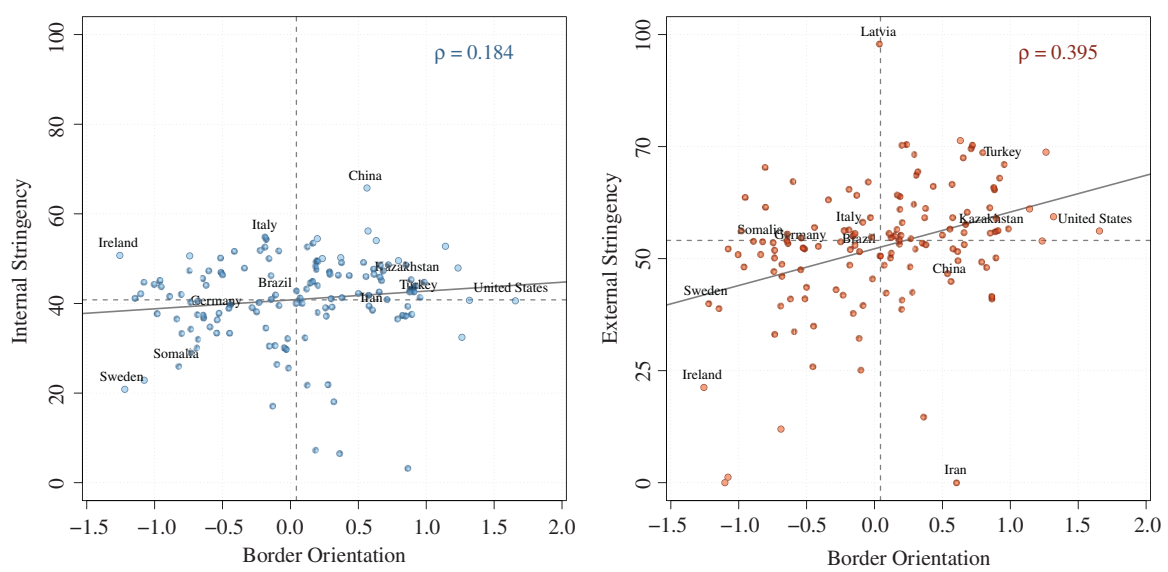

Notes: Average stringency scores since 1 January reported on vertical axes. Border orientation data obtained from Simmons and Kenwick 2020, stringency data generated from Hale et al. 2020.

FIGURE 5. Border orientation is more strongly associated with external rather than internal control measures to combat COVID-19

Figure 6 compares the average degree of internal and external stringency across time. The left panel compares internal stringency to the days preceding or since a country's first confirmed death to adjust for the degree of exposure to the virus. The right panel tracks calendar date since external measures are more responsive to the global, rather than to domestic outbreak. In the latter case, countries with more controlling border orientations (red) implemented external controls more quickly and maintained them for longer than countries with intermediate (black) or permissive (green) border orientations. By contrast, there is less variation in the application of internal control measures, and here these countries were slightly slower to implement restrictions in the early days of the virus, at least compared to countries with average border orientation scores.

Several mitigating factors complicate the interpretation of Figures 5 and 6, the most obvious of which is that border orientation tends to covary with wealth. While there are notable exceptions, richer countries tend to invest more to project control over their borders than do lower income countries. ${ }^{62}$ It is therefore difficult to disentangle whether some of the low-level responses observed among countries with permissive orientations (i.e., the green lines in Figure 6) were driven by a lack of will or a lack of capacity. 
We therefore perform a simple regression analysis, reported in Table 1, to control for a small set of potential confounders. The dependent variable is the average stringency of COVID response measures throughout the observation period, with average internal stringency reported in models $1-4$, and average external stringency in models 5-8. In addition to logged GDP per capita we report models that control for a country's liberal democracy score and its logged population. ${ }^{63} \mathrm{We}$ also include a quadratic interaction term for GDP to account for the fact that low-level responses to coronavirus have been observed at both low and high levels of the development spectrum.
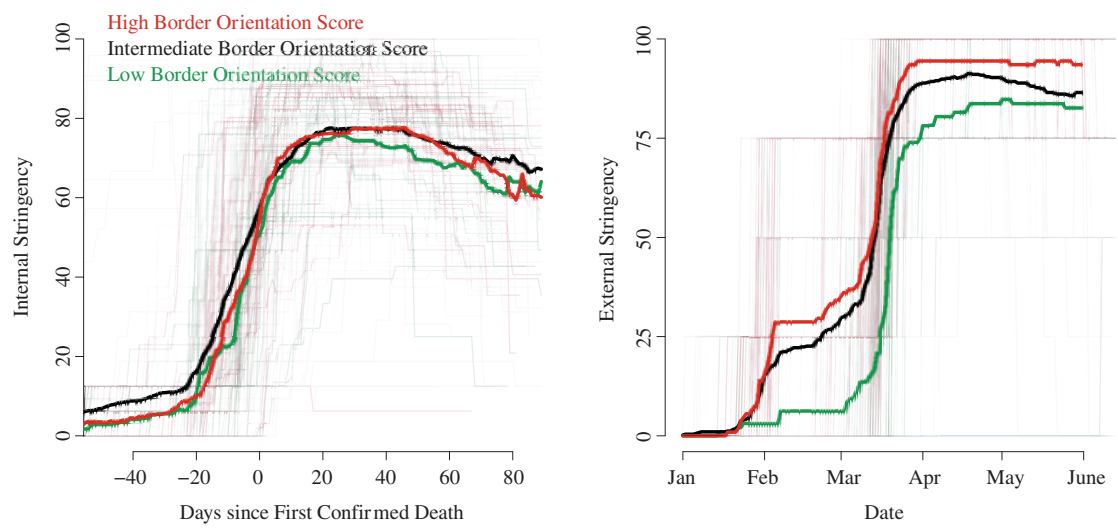

Notes: Border orientation scores above 0.56 displayed in red, below 0.56 in green, with intermediate scores in black. Bold lines report average stringency within each group. Border orientation data obtained from Simmons and Kenwick 2020, stringency data generated from Hale et al. 2020.

FIGURE 6. Countries with controlling border orientations implement external controls more quickly relative to internal control measures

The results present a striking picture. Across all model specifications, countries with prior investments projecting control over their borders were significantly more likely to implement rigid external control measures in response to the virus than those without such investments. By contrast, the relationship between border orientation and internal stringency is never significant. Mirroring Figure 5, when border orientation is run in a bivariate regression with the stringency of internal control measures, there is a positive, albeit insignificant association. After controlling for wealth, however, the association actually becomes negative, and remains so in all subsequent regressions. ${ }^{64}$

63. Data on GDP and population come from the World Bank (2020), while democracy is measured using the V-Dem liberal democracy index (Coppedge et al. 2020). Population data are from 2019. We use 2017 GDP data due to slightly more missingness in recent years.

64. The relationship between wealth and stringency is parabolic, with stringency highest among moderately rich states and lower among both the poorest and the wealthiest. More research is necessary to 
TABLE 1. Correlates of COVID-19 stringency measures

\begin{tabular}{|c|c|c|c|c|c|c|c|c|}
\hline \multirow[b]{2}{*}{ Dependent Variable } & \multicolumn{4}{|c|}{ Stringency of Internal Measures } & \multicolumn{4}{|c|}{ Stringency of External Measures } \\
\hline & (1) & (2) & (3) & (4) & (5) & (6) & (7) & (8) \\
\hline Border Orientation & $\begin{array}{c}1.977 \\
(1.309)\end{array}$ & $\begin{array}{c}-0.925 \\
(1.420)\end{array}$ & $\begin{array}{c}-0.550 \\
(1.525)\end{array}$ & $\begin{array}{c}-0.884 \\
(1.504)\end{array}$ & $\begin{array}{l}0.328 * \\
(0.073)\end{array}$ & $\begin{array}{c}0.249^{*} \\
(0.083)\end{array}$ & $\begin{array}{c}0.240 * \\
(0.089)\end{array}$ & $\begin{array}{c}0.245^{*} \\
(0.089)\end{array}$ \\
\hline Logged GDP Per Capita & & $\begin{array}{c}26.452 * \\
(6.829)\end{array}$ & $\begin{array}{c}26.284 * \\
(6.974)\end{array}$ & $\begin{array}{c}26.827^{*} \\
(6.850)\end{array}$ & & $\begin{array}{c}0.986^{*} \\
(0.398)\end{array}$ & $\begin{array}{l}1.042 * \\
(0.404)\end{array}$ & $\begin{array}{l}1.030^{*} \\
(0.405)\end{array}$ \\
\hline Logged GDP Per Capita² & & $\begin{array}{c}-1.464 * \\
(0.393)\end{array}$ & $\begin{array}{c}-1.465^{*} \\
(0.406)\end{array}$ & $\begin{array}{c}-1.498^{*} \\
(0.399)\end{array}$ & & $\begin{array}{c}-0.058^{*} \\
(0.023)\end{array}$ & $\begin{array}{c}-0.062^{*} \\
(0.024)\end{array}$ & $\begin{array}{r}-0.061^{*} \\
(0.024)\end{array}$ \\
\hline V-Dem Liberal Democracy & & & $\begin{array}{c}2.646 \\
(4.611)\end{array}$ & $\begin{array}{c}4.467 \\
(4.593)\end{array}$ & & & $\begin{array}{c}0.191 \\
(0.266)\end{array}$ & $\begin{array}{r}-0.025 \\
(0.035)\end{array}$ \\
\hline Logged Population & & & & $\begin{array}{l}1.422 * \\
(0.602)\end{array}$ & & & & $\begin{array}{c}0.157 \\
(0.271)\end{array}$ \\
\hline Observations & 137 & 132 & 127 & 127 & 138 & 133 & 128 & 128 \\
\hline
\end{tabular}

Notes: Intercepts omitted. $* p<.05$ 
That countries predisposed to displaying authority at their borders are more likely to implement external restrictions is perhaps not surprising, but that these measures were not paired with commensurate action at home points to two worrying possibilities. The first is that external controls may be either explicitly or implicitly seen as policy substitutes, a regrettable conclusion when the coronavirus has already permeated virtually every border in the world. ${ }^{65}$ The second is that border orientation may be associated with externalizing public health adjustment costs onto foreigners, undermining beneficial transactions, stoking blame, and reducing possibilities for international cooperation in the future.

These results must be interpreted with caution — both the political and global health environments are still in flux, and policy responses are rapidly evolving. Nevertheless, this analysis is intended to characterize whether countries concerned with border security adopted externalizing policy responses to COVID-19, and indeed this appears to be the case. Additional testing is clearly necessary to isolate the causal mechanisms underlying these correlations and to explore any possible impacts of doubling down on border security for the future of global pandemic control.

\section{Conclusion}

When responding to the H5N1 virus, then-senators Barack Obama and Richard Lugar warned that "exotic killer diseases are not isolated health problems half a world away, but direct and immediate threats to security and prosperity here at home." ${ }^{66}$ How states respond to such "exotic killers" impacts millions of lives worldwide. One hopes that these responses are informed by science, but it is clear that they are formulated under uncertainty and shaped by fear. Leaders are paramount in providing appropriate information and assuaging these fears, but our research suggests that they are also likely to draw from some of the same narratives, symbols and capabilities in which the state has invested in the past.

Pandemic responses are imbued with border politics. States that have invested heavily in border security tend to want to redeploy those investments in fighting global pandemics. As we have shown, border anxiety seems to be on the rise worldwide. Residents in some states seem very willing to close borders before staying home, even though the virus is already spreading domestically. Under these conditions, closing an international border may assuage some anxiety at low personal cost.

confirm, but a possible explanation may be that wealth is correlated with respect for civil liberties, which may sometimes clash with perceptions of "authoritarian" restrictions on freedom ("we are not China"). Low-income countries have low capacity to do any of these things. The apex of the parabola-the peak in the middle-may represent the conjunction of preferences and means for internal control.

65. To be clear: we are not presenting these results as causal proof of policy substitution, which would require a much more nuanced approach than presentation of two separate regressions.

66. Remarks of US Senator Barack Obama, Foreign Operations Appropriations Bill and the Avian Flu, July 18, 2005. Available at <http://obamaspeeches.com/026-Foreign-Operations-Appropriations-Bill-andthe-Avian-Flu-Obama-Speech.htm>. Accessed 21 July 2020. 
We have argued that polities have latent traits that become manifest in their investments in the built environment along international borders. This border orientation is associated with a distinctive externally-focused response to pandemics. There is even some suggestive evidence that it may be associated with policy substitution-the avoidance of more effective domestic mitigation strategies. Much more research should be done to understand how narratives and structures from past border investments and security debates play into public health responses. The concept of border orientation is useful in this regard: it allows us to explore the extent to which states return to old scripts in the face of novel threats. Responses to this particular crisis may have been shaped as much by pre-existing anxieties as by scientific innovation. The concept of border orientation gives special insights into these choices.

Two broader points can be made about what scholars of international relations can learn about international borders from this global public health crisis. First, borders are not going away anytime soon. Long before the onset of the coronavirus pandemic, many scholars were grappling with the rise and apparent demise of globalization and its ramifications for the broader study of global politics and the neoliberal international order. ${ }^{67}$ While it is too soon to make firm declarations about the full impact of the coronavirus pandemic, it seems to have accelerated trends toward border hardening that predate COVID-19. While the increased pace of movement wrought by globalization may one day return, it appears that the current pandemic has hastened movement away from international cooperation and reinvigorated a my-nation-first approach.

Second, we suggest that in addition to the traditional study of interstate border claims, researchers should view international borders as a potential domestic political resource. The current crisis shows how convenient it is, and how well it resonates politically, to assure domestic audiences that national leaders are taking prudent measures to protect them while minimizing the impact on daily life. International border politics is a useful tool in this regard. Clearly, border policies are at the nexus of comparative and international politics and involve security as well as political economy concerns. A better understanding of these policies will require both objective data and the application of intersubjective concepts.

\section{Data Availability Statement}

Replication files for this research note may be found at <https:/doi.org/10.7910/ DVN/JOPGNY>.

\section{References}

Almond, Brenda. 2016. Border Anxiety: Culture, Identity and Belonging. Philosophy 91 (4):463-81.

67. See International Organization, $75^{\text {th }}$ Anniversary Issue (forthcoming). 
Arhin-Tenkorang, Dyna, and Pedro Conceição. 2003. Beyond Communicable Disease Control: Health in the Age of Globalization. In Providing Global Public Goods: Managing Globalization, edited by Kaul, Inge, Pedro Conceicao, Katell Le Goulven, and Ronald U. Mendoza, 484-515. Oxford University Press.

Avdan, Nazli and Christopher Gelpi. 2017. Do Good Fences Make Good Neighbors? Border Barriers and the Transnational Flow of Terrorist Violence. International Studies Quarterly 61(1):14-27.

Backus, Matthew, and Andrew Little. forthcoming. I Don't Know. American Political Science Review.

Baker, Scott R., Nicholas Bloom, Steven J. Davis, and Stephen J. Terry. 2020. Covid-Induced Economic Uncertainty. National Bureau of Economic Research.

Balzacq, Thierry. 2005. The Three Faces of Securitization: Political Agency, Audience and Context. European Journal of International Relations 11 (2):171-201.

Bier, David J. 2020. "Research Provides No Basis for Pandemic Travel Bans." CATO Institute. Available at $<$ https://www.cato.org/blog/research-provides-no-basis-pandemic-travel-bans>. Accessed 21 July 2020.

Boyd, Matt, Michael G. Baker, Osman D. Mansoor, Giorgi Kvizhinadze, and Nick Wilson. 2017. Protecting an Island Nation from Extreme Pandemic Threats: Proof-of-Concept Around Border Closure as an Intervention. PloS one 12 (6): $\mathrm{e} 0178732$.

Buranyi, Stephen. 2020. The WHO v Coronavirus: Why it Can't Handle the Pandemic. The Guardian, April 10. Available at <https://www.theguardian.com/news/2020/apr/10/world-health-organizationwho-v-coronavirus-why-it-cant-handle-pandemic >. Accessed 31 July 2020.

Cacciapaglia, Giacomo, and Francesco Sannino. 2020. Interplay of Social Distancing and Border Restrictions for Pandemics (Covid-19) Via the Epidemic Renormalisation Group Framework. Available at $<\langle$ hal-02863120 $\rangle$. Accessed 29 July 2020.

Carter, David B., and Paul Poast. 2015. Why Do States Build Walls? Political Economy, Security, and Border Stability. Journal of Conflict Resolution, 61 (2):239-70

Carter, Teri. 2020. In My Red State, People See Masks as Unmanly. That's Trump's Fault. Washington Post, June 1. Available at <https://www.washingtonpost.com/outlook/2020/06/01/red-states-like-minepeople-see-masks-un-manly-that'strumps-fault/>. Accessed 21 July 2020.

Cheng, Cindy, Joan Barcelo, Allison S. Hartnett, Robert Kubinec, and Luca Messerschmidt. 2020. Tracking Governments Responses to COVID-19. CoronaNet. Available at $<\mathrm{https} / / / \mathrm{www}$.coronanetproject.org/>. Accessed 21 July 2020.

Cliff, Andrew D., Matthew R. Smallman-Raynor, and Peta M. Stevens 2009. Controlling the Geographical Spread of Infectious Disease: Plague in Italy, 1347-1851. Acta medico-historica Adriatica 7 (2): 197-236.

Cooper, Richard N. 2001. International Cooperation in Public Health as a Prologue to Macroeconomic Cooperation. In Can Nations Agree?: Issues in International Economic Cooperation, edited by Richard N. Cooper, Barry Eichengreen, Gerald Holtham, Robert D. Putnam and C. Randall Henning, 178-254. Brookings Institution Press.

Coppedge, Michael, John Gerring, Carl Henrik Knutsen, Staffan I. Lindberg, Jan Teorell, David Altman, Michael Bernhard, M. Steven Fish, Adam Glynn, Allen Hicken, Anna Lührmann, Kyle L. Marquardt, Kelly McMann, Pamela Paxton, Daniel Pemstein, Brigitte Seim, Rachel Sigman, Svend-Erik Skaaning, Jeffrey Staton, Steven Wilson, Agnes Cornell, Nazifa Alizada, Lisa Gastaldi, Haakon Gjerløw, Garry Hindle, Nina Ilchenko, Laura Maxwell, Valeriya Mechkova, Juraj Medzihorsky, Johannes von Römer, Aksel Sundström, Eitan Tzelgov, Yi-ting Wang, Tore Wig, and Daniel Ziblatt. 2020. V-Dem [Country-Year/Country-Date] Dataset v10. Varieties of Democracy (V-Dem) Project. Available at $<$ https://doi.org/10.23696/vdemds20 $>$.

Davis, Mark. 2019. Uncertainty and Immunity in Public Communications on Pandemics. In Pandemics, Publics, and Politics, edited by Kristian Bjørkdahl and Benedicte Carlsen, 29-42. Springer.

Elbe, Stefan. 2010. Pandemic Security. In The Routledge Handbook of New Security Studies, edited by J. Peter Burgess, 163-72. Routledge.

Euronews. 2020. World Health Organization: Don't Expect Travel Bans to Beat Coronavirus. March 13. Available at <https://www.euronews.com/2020/03/13/world-health-organization-don-t-expect-travelbans-to-beat-coronavirus>. Accessed 21 July 2020.

Fidler, David P. 1999. International Law and Infectious Diseases. Oxford University Press. 
Fidler, David P. 2004. SARS, Governance and the Globalization of Disease. Springer.

Goemans, Hein E., and Kenneth A. Schultz 2016. The Politics of Territorial Claims: A Geospatial Approach Applied to Africa. International Organization 71 (1):31-64.

Guterres, António. 2020. This War Needs a War-time Plan to Fight it. March 20. Available at <https:// www.un.org/en/coronavirus/war-needs-war-time-plan-fight-it>. Accessed 21 July 2020.

Hale, Thomas, Sam Webster, Anna Petherick, Toby Phillips, and Beatriz Kira. 2020. Oxford COVID-19 Government Response Tracker. Blavatnik School of Government. Data use policy: Creative Commons Attribution CC BY standard. Available at <https://www.bsg.ox.ac.uk/research/research-projects/coronavirus-government-response-tracker>. Accessed 21 July 2020.

Hassner, Ron E., and Jason Wittenberg. 2015. Barriers to Entry: Who Builds Fortified Boundaries and Why? International Security 40 (1):157-90.

Kamradt-Scott, Adam, and Colin McInnes. 2012. The Securitisation of Pandemic Influenza: Framing, Security and Public Policy. Global Public Health 7 (suppl. 2): S95-S110.

Karlsen, André, and Bjørn Ivar Kruke. 2018. The Role of Uncertainty During the Ebola Pandemic in Western Africa (2014-2016). Journal of Extreme Events 5 (01):1850009.

Kenny, Charles. 2020. Pandemics Close Borders-and Keep Them Closed. Politico Magazine, March 25. Available at $<$ https://www.politico.com/news/magazine/2020/03/25/trump-coronavirus-borders-historyplague-146788>. Accessed 21 July 2020.

Landler, Mark. 2020. Boris Johnson Hospitalized as Queen Urges British Resolve in Face of Epidemic. New York Times, April 5. Available at <https://www.nytimes.com/2020/04/05/world/europe/coronavirus-queen-elizabeth-speech.html>. Accessed 21 July 2020.

Leduc, Sylvain, and Zheng Liu. 2020. The Uncertainty Channel of the Coronavirus. FRBSF Economic Letter 2020 (07): 1-5.

Lemire, Jonathan. 2020. As Coronavirus Cases Surge Nationally, President Trump Shifts Attention to USMexico Border Wall. Time. June 23. Available at <https://time.com/5858294/trump-border-wall-coronavirus/>. Accessed 21 July 2020.

Lipsitch, Marc, Steven Riley, Simon Cauchemez, Azra C. Ghani, and Neil M. Ferguson 2009. Managing and Reducing Uncertainty in an Emerging Influenza Pandemic. New England Journal of Medicine 361 (2):112-15.

Luan, Shenghua, Jochen Reb, and Gerd Gigerenzer. 2019. Ecological Rationality: Fast-and-Frugal Heuristics for Managerial Decision Making Under Uncertainty. Academy of Management Journal $62(6): 1735-59$.

Manela, Erez. 2010. A Pox on Your Narrative: Writing Disease Control into Cold War History. Diplomatic History 34 (2):299-323.

McNeil, Donald G. Jr. 2014. Using a Tactic Unseen in a Century, Countries Cordon Off Ebola-Racked Areas. New York Times, August 12. Available at <https://www.nytimes.com/2014/08/13/science/using-a-tacticunseen-in-a-century-countries-cordon-off-ebola-racked-areas.html>. Accessed 21 July 2020.

Michelle Driedger, S., Ryan Maier, and Cindy Jardine. 2018. 'Damned If You Do, and Damned If You Don't': Communicating About Uncertainty and Evolving Science During the H1n1 Influenza Pandemic. Journal of Risk Research: Available at <https://doi.org/10.1080/13669877.2018.1459793>. Accessed 29 July 2020.

Morens, David M., and Jeffery K. Taubenberger 2011. Pandemic Influenza: Certain Uncertainties. Reviews in Medical Virology 21 (5):262-84.

Pedersen, Susan. 2007. Back to the League of Nations. The American Historical Review 112 (4):1091-117. PPD Elections Staff. 2020. Poll: 8 in 10 Americans Support Travel Bans on China and Europe to Limit Coronavirus Spread. People's Pundit Daily. Available at <https://www.peoplespunditdaily.com/polls/ 2020/03/18/8-in-10-americans-support-travel-bans-on-china-and-europe-to-limit-coronavirus-spread/> . Accessed 21 July 2020.

Simmons, Beth A. 2019. Border Rules. International Studies Review 21 (2):256-83.

Simmons, Beth A., and Michael Kenwick. 2020. Border Orientation in a Globalizing World: Concept and Measurement. Working Paper. Available at SSRN 3326773. 
Simmons, Beth A., and Robert Shaffer. 2019. Globalization and Border Securitization in International Discourse. Working Paper. Available at SSRN 3480613.

Stowman, Knud. 1952. International Sanitary Regulations. Public Health Reports 67 (10):972.

Stritzel, Holger. 2007. Towards a Theory of Securitization: Copenhagen and Beyond. European Journal of International Relations 13 (3):357-83.

Versluis, Esther, Marjolein van Asselt, and Jinhee Kim. 2019. The Multilevel Regulation of Complex Policy Problems: Uncertainty and the Swine Flu Pandemic. European Policy Analysis 5 (1):80-98.

Washington Post. 2020. In Coronavirus Crisis, Trump Says he is a 'Wartime President.' March 23. Video available at $<$ https://www.washingtonpost.com/video/national/in-coronavirus-crisis-trump-says-he-is-awartime-president-heres-what-thats-meant-in-the-past/2020/03/23/5eb1 ef02-49cb-44b3-aa65f35802166507_video.html>. Accessed 21 July 2020.

Wæver, Ole. 1995. Securitization and Desecuritization. In On Security, edited by Ronnie Lipschutz, 46-86. Columbia University Press.

Wells, Chad R., Pratha Sah, Seyed M. Moghadas, Abhishek Pandey, Affan Shoukat, Yaning Wang, Zheng Wang, Lauren A. Meyers, Burton H. Singer, and Alison P. Galvani 2020. Impact of International Travel and Border Control Measures on the Global Spread of the Novel 2019 Coronavirus Outbreak. Proceedings of the National Academy of Sciences 117 (13):7504-9.

World Bank. 2020. World Development Indicators. Available at <:http://data.worldbank.org/data-catalog/ world-development-indicators>. Accessed 21 July 2020.

World Health Organization 1983. International Health Regulations (1969): Third Annotated Edition. Available at <https://apps.who.int/iris/handle/10665/224469>. Accessed 21 July 2020.

Zhu, Chelsey. 2020. U.S. Isn't the Only Country with Lockdown Protests. FactCheck.org, May 14. Available at <https://www.factcheck.org/2020/05/u-s-isnt-the-only-country-with-lockdown-protests>. Accessed 31 July 2020.

\section{Authors}

Michael R. Kenwick is Assistant Professor at Rutgers University. He can be reached at Michael.kenwick@rutgers.edu.

Beth A. Simmons is Andrea Mitchell University Professor in Law, Political Science, and Business Ethics at the University of Pennsylvania Carey Law School. She can be reached at simmons3@law.upenn.edu.

\section{Acknowledgments}

We are grateful for helpful comments from Michael Horowitz, Kathleen McNamara, Erik Voeten, and participants in the International Organization/University of Pennsylvania Perry World House workshop hosted in June 2020. For research assistance, we thank Jasmine Rawson and the Borders and Boundaries research labs at Rutgers University and the University of Pennsylvania.

\section{Funding}

This work was supported by the National Science Foundation, award number 1917573.

\section{Key words}

coronavirus; COVID-19; borders; territory 